\title{
Development of Three Loop-Mediated Isothermal Amplification (LAMP) Assays for the Rapid Detection of Calonectria ilicicola, Dactylonectria macrodidyma, and the Dactylonectria Genus in Avocado Roots
}

\author{
Louisamarie E. Parkinson, ${ }^{\dagger}$ Duy P. Le, and Elizabeth K. Dann \\ Queensland Alliance for Agriculture and Food Innovation, The University of Queensland, Dutton Park, Queensland 4102, \\ Australia
}

\begin{abstract}
Black root rot of avocado is a severe disease of nursery trees and young orchard transplants, causing tree death within a year after planting. In Australia, key pathogens include species complexes Calonectria ilicicola and Dactylonectria macrodidyma; however, several other Dactylonectria species also cause the disease. Rapid detection of these pathogens in planta is important to speed up implementation of disease management and reduce loss. The purpose of this study was to develop three loopmediated isothermal amplification (LAMP) diagnostic assays to rapidly identify species within the $C$. ilicicola and $D$. macrodidyma complexes and species in the Dactylonectria genus in avocado roots. Primers were designed from $\beta$-tubulin sequence data of $C$. ilicicola and from histone H3 of D. macrodidyma and the Dactylonectria genus. The LAMP primers were tested for specificity and sensitivity with 82 fungal isolates, which included the target species complexes C. ilicicola and D. macrodidyma; species within the target Dactylonectria genus viz. D. macrodidyma, D. anthuriicola, D. novozelandica, D. pauciseptata, and D. vitis; and isolates of nontarget species, including Calonectria sp., Cylindrocladiella sp., Gliocladiopsis forsbergii, G. peggii, G. whileyi, Ilyonectria

whereas the Dactylonectria genus-wide assay was sensitive to $0.1 \mathrm{ng} / \mu \mathrm{l}$. Detection of C. ilicicola occurred within 10 to 15 or 15 to $30 \mathrm{~min}$ when the template was pure DNA or crude extracts obtained from suspending fungal cultures in sterile water, respectively. Detection of D. macrodidyma was between 12 to 29 min with pure DNA and 16 to $30 \mathrm{~min}$ with crude extracts. Dactylonectria spp. were detected within 6 to 25 min with pure DNA and 7 to $23 \mathrm{~min}$ with crude extracts. The specificity of the assays was found to be dependent on time and isothermal amplification temperature, with optimal specificity occurring in reactions of $<30 \mathrm{~min}$ and at temperatures of $67^{\circ} \mathrm{C}$ for C. ilicicola and D. macrodidyma assays and $69^{\circ} \mathrm{C}$ for Dactylonectria genus-wide assays. The assays were modified to accommodate a DNA extraction step and use of avocado roots as DNA templates. Detection in avocado roots ranged between 12 to $25 \mathrm{~min}$ for $C$. ilicicola, 12 to $26 \mathrm{~min}$ for D. macrodidyma, and 14 to $30 \mathrm{~min}$ for species in the Dactylonectria genus. The LAMP assays are applicable across multiple agricultural industries, because C. ilicicola, D. macrodidyma, and Dactylonectria spp. are also important pathogens of various crops and ornamental plants.
\end{abstract} sp., Mariannaea sp., Fusarium sp., and Phytophthora cinnamomi. The species-specific LAMP assays were sensitive and specific at DNA concentrations of $1 \mathrm{pg} / \mu \mathrm{l}$ for $C$. ilicicola and $0.01 \mathrm{ng} / \mu \mathrm{l}$ for $D$. macrodidyma,
Keywords: fungi, Nectriaceae, nectriaceous fungi, pathogen detection, Persea americana, techniques, tropical plants
Black root rot of avocado caused by soilborne nectriaceous pathogens is an important disease of nursery trees and young orchard transplants, causing tree stunting; wilt; black, rotten, and necrotic roots; and rapid tree decline and death within a year after planting (Parkinson et al. 2017). In Australia and globally, the important pathogens are Calonectria ilicicola (Dann et al. 2012) and Dactylonectria macrodidyma (Ilyonectria macrodidyma in Vitale et al. 2012). However, other studies have demonstrated that other species within these genera cause black root rot, including an undescribed Calonectria sp., Dactylonectria anthuriicola, Dactylonectria novozelandica,

Current address of D. P. Le: New South Wales Department of Primary Industries, Narrabri, NSW 2390, Australia.

${ }^{\dagger}$ Corresponding author: L. E. Parkinson; 1.parkinson@uq.edu.au

Funding: This work was supported by Hort Innovation grant AV14012, which used the avocado research and development levy and contributions from the Australian Government. This project was jointly supported by the Queensland Department of Agriculture and Fisheries and the University of Queensland. L. E. Parkinson was a recipient of an Australian Postgraduate Award Scholarship from the Australian Federal Government.

*The $\boldsymbol{e}$-Xtra logo stands for "electronic extra" and indicates that three supplementary tables are published online.

The author(s) declare no conflict of interest.

Accepted for publication 6 February 2019.

(c) 2019 The American Phytopathological Society and Dactylonectria pauciseptata (Parkinson et al. 2017). These pathogens are a threat to new plantings, and the disease can potentially be undetected in young nursery trees, because above ground symptoms of stunting and wilt may not develop until after outplanting (Parkinson et al. 2017). The Australian Avocado Nursery Voluntary Accreditation Scheme involves regular sampling of nursery material and testing by plant pathologists for a nursery to maintain diseasefree accreditation. Standard diagnostic practices include diagnosing disease from symptomatic plant tissue, isolating and culturing the causal agents on selective media, and identifying microbial species by microscopy. In instances where a suspected pathogen is difficult to identify with microscopy alone (for example, nectriaceous genera, which have similar morphology), molecular techniques have been extremely useful to aid accurate identification. Molecular identification of suspect isolates to species level by isolation, establishment of pure cultures, microscopy, DNA extraction, polymerase chain reaction (PCR), and sequencing requires time and can take several days to weeks to achieve a diagnosis (Niessen 2015; Notomi et al. 2015). There is demand for rapid, sensitive, and specific molecular methods for early detection of plant diseases (Sankaran et al. 2010) to enable faster implementation of disease management strategies and reduce commercial loss (Fang and Ramasamy 2015).

Loop-mediated isothermal amplification (LAMP) is a rapid, highly specific, and sensitive nucleic acid amplification technique that uses autocycling strand displacement DNA synthesis and produces results from diseased plant tissue in $<60 \mathrm{~min}$ (Fu et al. 2011; Notomi et al. 2000). LAMP is catalyzed by the $B s t$ DNA polymerase and uses four primers that recognize six specific sequences on the target DNA (Niessen 2015). The reaction is initiated by an inner primer, which contains the sense and antisense strand sequence of target 
DNA (Fu et al. 2011), called the F1 and F2 or B1 and B2 sequence (Notomi et al. 2000). These inner primers are called forward inner primer (FIP) and backward inner primer (BIP) (Notomi et al. 2000). A single-stranded synthesized DNA is released by an outer primer (Fu et al. 2011), called the F3 or B3 Primer, and this is used as a template for a second inner and outer primer (Notomi et al. 2000). On the other end of the target sequence, the second inner and outer primers hybridize to the target and produce a stem-loop DNA structure (Fu et al. 2011). In the cycles that follow, one inner primer hybridizes to the loop and initiates displacement DNA synthesis, which produces the original stem-loop structure and a new stemloop DNA sequence with a stem twice as long (Notomi et al. 2000). The cycling of DNA displacement synthesis results in stem-loop DNA strands with several inverted repeats of the target DNA and loop structures (Notomi et al. 2000). Additional LAMP primers called loop primers (forward-loop [F Loop] and backward-loop [B Loop] primers) can be added to the reaction to dramatically reduce detection time (Niessen 2015) and increase the specificity and sensitivity of detection (Nagamine et al. 2002). Loop primers recognize and anneal to target DNA sequences between the F1 and F2 sequence and between the B1 and B2 sequence (Nagamine et al. 2002), providing broader coverage of a length of nucleotide sequences to be detected.

An advantage of LAMP is that the diagnostic is portable and simple to use (Notomi et al. 2015). Because it uses one continuous temperature, the reaction can also be carried out in a water bath or heating block (Notomi et al. 2000) using alternative reaction reagents, enabling cost-effective options (Fu et al. 2011) and accessibility in developing countries and resource-poor areas (Mori and Notomi 2009); detection is simplified by visualizing salt precipitation or fluorescence in the reaction tube (Tomita et al. 2008). LAMP offers the equivalent or better sensitivity and specificity of PCR (Fukuta et al. 2013, Vincelli and Tisserat 2008), and the LAMP procedure requires fewer preparation steps (Fu et al. 2011).

LAMP-based diagnostic methods have been developed for various plant pathogens, including some nectriaceous fungi, such as Boxwood blight fungi, Calonectria henricotiae, Calonectria pseudonaviculata (Malapi-Wight et al. 2016), and Fusarium oxysporum f. sp. ciceris of chickpea (Ghosh et al. 2015). So far, no LAMP assays exist for detecting Dactylonectria spp.

LAMP-based assays for detecting C. ilicicola and Dactylonectria spp. would be extremely useful for the timely identification of causal organisms and disease management for many horticultural, ornamental, and field crop industries. For example, C. ilicicola also causes crown and root rot of other Lauraceae trees, such as bay laurel (Polizzi et al. 2012); collar rot of papaya (Male et al. 2012); leaf spot in ornamental holly (Lechat et al. 2010); and diseases of various field crops, including Cylindrocladium black rot of peanut (as Cylindrocladium parasiticum in Wright et al. 2010) and crown rot of soybean (Ochi et al. 2011). D. macrodidyma causes black foot disease of grapevine (as Cylindrocarpon macrodidymum in Halleen et al. 2004), root rot of olive (as I. macrodidyma in Úrbez-Torres et al. 2012), and cherimoya (Auger et al. 2015), and it is associated with apple seedling replant disease (as $C$. macrodidymum in Tewoldemedhin et al. 2011) and dry root rot of citrus (as Neonectria macrodidyma in Adesemoye et al. 2016).

This investigation aimed to develop LAMP assays for the detection of two key nectriaceous pathogens, C. ilicicola and D. macrodidyma, and a genus-wide assay for detecting Dactylonectria spp. in avocado roots. The procedures involved (i) assessing multiple alignments of gene sequence data of a large collection of nectriaceous fungal isolates to identify genes with high nucleotide variation between species, (ii) selecting candidate genes and designing specific LAMP primers from species or genus-unique nucleotide sequences, and (iii) demonstrating the specificity, sensitivity, and rapid detection of the LAMP assay using DNA extracts, fungal cultures, and inoculated plant tissue. The C. ilicicola and D. macrodidyma isolates used in this study were part of species complexes, each containing potentially new and unresolved species within the phylogenetic clade of the target species (Parkinson 2017). The LAMP primers were designed to detect all members of the $C$. ilicicola and $D$. macrodidyma species complexes, and these were treated as single species in the LAMP assay design.

\section{Materials and Methods}

Fungal isolates. Two species-specific LAMP assays for use with avocado roots were designed for detecting black root rot pathogens, C. ilicicola and D. macrodidyma, and a genus-wide assay was developed for detecting species in the genus Dactylonectria. Eighty-two fungal isolates from the Biosecurity Queensland Plant Pathology Herbarium (BRIP), Department of Agriculture and Fisheries (Brisbane, Queensland) were included this study for demonstrating diagnostic specificity. The isolates tested included a representative number of target species, closely related species, and distantly related species (Supplementary Table S1).

Designing LAMP primers. Type DNA sequence data of the $\beta$-tubulin and histone $\mathrm{H} 3$ genes of species in the genera Calonectria and Dactylonectria were downloaded from GenBank (https:// www.ncbi.nlm.nih.gov/). DNA was extracted from BRIP fungal isolates of the genera Calonectria and Dactylonectria, and the $\beta$-tubulin and histone $\mathrm{H} 3$ gene regions were sequenced following the methods described in Parkinson et al. (2017).

A multiple alignment of the $\beta$-tubulin and histone $\mathrm{H} 3$ individual gene regions was performed on each genus in Geneious v 7.1.9 (Biomatters Ltd) (Kearse et al. 2012) using the MAAFT Alignment (Katoh and Standley 2013) plugin and included sequence data of fungal species from related genera to identify gene regions unique to the target genus. The $\beta$-tubulin gene was selected for designing LAMP primers for C. ilicicola, and the histone $\mathrm{H} 3$ gene was selected for designing primers for D. macrodidyma and Dactylonectria spp., because these genes contained high sequence variation between species within the genus to enable target-specific primer annealing. $\beta$-tubulin was initially considered for $D$. macrodidyma; however, there was no sufficient sequence variation to design $D$. macrodidyma-specific LAMP primers.

Unique nucleotide sequences were identified for C. ilicicola and D. macrodidyma and used as the basis for designing specific LAMP primers and genus-specific Dactylonectria primers. For the $C$. ilicicola and D. macrodidyma assays, the outer F3 and B3 LAMP primers were designed from the unique sequences, and these were used to generate the FIP, BIP, F Loop, and B Loop primers in the LAMP primer designing software, Primer Explorer v 4 (http://primerexplorer.jp) (Table 1). These primer sets were modified manually.

For the genus-wide Dactylonectria assay, the consensus sequence of the genus-wide alignment was used as the backbone for designing LAMP primers. Histone $\mathrm{H} 3$ sequence data of the closely related genus Ilyonectria were included to ensure genus specificity. The F3, B3, FIP, BIP, F Loop, and B Loop primers (Table 1) were designed manually from the consensus sequence, and the target sequence of each primer was checked in the alignment for specificity to the target genus. Multiple combinations of the LAMP primers were tested in experiments for sensitivity, specificity, and optimal isothermal conditions. All LAMP optimization, sensitivity, and specificity experiments with pure fungal DNA and crude extracts obtained from suspending fungal cultures in sterile water were conducted once, whereas LAMP assays with avocado roots were performed twice.

Optimization of LAMP reactions. Experiment 1: Initial sensitivity and specificity testing and optimizing isothermal conditions. Experiment 1 tested the designed primers to confirm primer specificity, revealed an approximate level of sensitivity for detection, and determined the optimal isothermal temperature at which detection is the fastest. Unless otherwise stated, all isothermal reactions in this study were carried out using OptiGene Isothermal Master Mix and the isothermal block Genie II supplied by GeneWorks Pty Ltd.

The working primer mixture was made to $100 \mu$ l containing $1.25 \mu \mathrm{M}$ F3 primer, $1.25 \mu \mathrm{M}$ B3 primer, $10 \mu \mathrm{M}$ FIP primer, $10 \mu \mathrm{M}$ BIP primer, and RNAase-free water. The reaction mixture for each test sample contained a total volume of $15 \mu$ composed of $2.6 \mu$ l RNAase-free water, $9 \mu$ l OptiGene Isothermal Master 
Mix, $2.4 \mu \mathrm{l}$ working primer mixture, and $1 \mu \mathrm{l}$ DNA template of fungal DNA extracts at concentrations ranging from $0.01 \mathrm{pg} / \mu \mathrm{l}$ to $1 \mathrm{ng} / \mu \mathrm{l}$. The template-free negative control in each LAMP diagnostic test run was RNase-free water.

For the species-specific assays, Genie II was set at $65^{\circ} \mathrm{C}$ for $60 \mathrm{~min}$ followed by 95 to $80^{\circ} \mathrm{C}$ annealing and termination rate of $0.5^{\circ} \mathrm{C} / \mathrm{s}$. If sensitivity was demonstrated at a DNA concentration $<0.01 \mathrm{ng} / \mu \mathrm{l}$, the experiment was repeated using 63 and $67^{\circ} \mathrm{C}$ isothermal amplification temperatures to determine the best isothermal temperature conditions for the LAMP diagnostic. The optimal isothermal temperature was used in subsequent experiments. The Dactylonectria genus-wide assay used an isothermal amplification temperature of $67^{\circ} \mathrm{C}$ and the same reaction parameters as the species-specific assays.

In reactions where target species were not detected when DNA concentrations of $<0.01 \mathrm{ng} / \mu \mathrm{l}$ were tested, isothermal temperature comparisons and selection were made in experiment 2, where loop primers were introduced to the reaction and the optimal LAMP primer combination was determined.

Experiment 2: Testing loop primers for improved detection time, sensitivity, and specificity of species-specific LAMP assays. F Loop and B Loop primers were introduced individually or in combination with the LAMP reaction to test for increased reaction speed and improved sensitivity and specificity. The LAMP reagents and sample concentrations were as outlined in experiment 1 ; however, the working primer mixture contained $5 \mu \mathrm{M}$ F Loop primer, $5 \mu \mathrm{M}$ B Loop primer, or both primers each at $5 \mu \mathrm{M}$ concentration.

Isothermal amplification for detecting C. ilicicola was at $67^{\circ} \mathrm{C}$ for $60 \mathrm{~min}$ followed by 95 to $80^{\circ} \mathrm{C}$ annealing and termination at $0.5^{\circ} \mathrm{C} / \mathrm{s}$. The test samples for the $D$. macrodidyma diagnostic underwent the same reaction conditions; however, the isothermal amplification temperature was set to $65^{\circ} \mathrm{C}$. In both diagnostics, the best loop primer combination was selected from comparing the reaction times, sensitivity, and specificity, and this primer set was used in additional LAMP experiments.

For the D. macrodidyma diagnostic, additional experiments that compared isothermal amplification temperatures of 63, 65, and $67^{\circ} \mathrm{C}$ were carried out using the selected loop primer set to determine the optimal reaction conditions for this diagnostic. The selected temperature was used in the following experiments.

In the Dactylonectria genus-wide assay, the LAMP reaction parameters were set to $67^{\circ} \mathrm{C}$ for $45 \mathrm{~min}$ followed by 95 to $80^{\circ} \mathrm{C}$ annealing and termination at $0.5^{\circ} \mathrm{C} / \mathrm{s}$. The LAMP reaction components and master mix were as listed above and underwent additional testing for sensitivity using DNA between $1 \mathrm{ng} / \mu \mathrm{l}$ and $0.1 \mathrm{pg} / \mu \mathrm{l}$ following the master mix requirements listed above. Isothermal amplification was at $67^{\circ} \mathrm{C}$ for $60 \mathrm{~min}$ followed by 95 to $80^{\circ} \mathrm{C}$ annealing and termination at $0.5^{\circ} \mathrm{C} / \mathrm{s}$, and then, it was repeated at $69^{\circ} \mathrm{C}$ for $30 \mathrm{~min}$ to test for an improvement in sensitivity.

Experiment 3: Screening DNA from multiple isolates to confirm LAMP specificity. The selected LAMP primer combination and isothermal amplification temperature with DNA templates of a representative number of isolates (target and nontarget species) were utilized to thoroughly confirm the specificity of all tests.

For both species-specific diagnostics, the working primer mixture was made to $100 \mu$ l containing $1.25 \mu \mathrm{M}$ F3 primer, $1.25 \mu \mathrm{M}$ B3 primer, $10 \mu \mathrm{M}$ FIP primer, $10 \mu \mathrm{M}$ BIP primer, $5 \mu \mathrm{M}$ B Loop primer and RNAase-free water. The Dactylonectria genus-wide assay utilized these reaction components; however, $5 \mu \mathrm{M}$ F Loop primer was also included. Each reaction was prepared as described in experiment 1 , with the fungal DNA template at a concentration of 1 or $50 \mathrm{ng} / \mu \mathrm{l}$ and RNase-free water as the template-free negative control (Table 2). For all three assays, the reaction parameters were $67^{\circ} \mathrm{C}$ isothermal amplification for $30 \mathrm{~min}$ followed by 95 to $80^{\circ} \mathrm{C}$ annealing and termination at $0.5^{\circ} \mathrm{C} / \mathrm{s}$. The Dactylonectria genus-wide assay was repeated with the same parameters and an additional isothermal amplification temperature of $69^{\circ} \mathrm{C}$ to test for an improvement in specificity.

LAMP diagnostic detection with fungal cultures and inoculated necrotic avocado tissue. Experiment 4: LAMP diagnostic for detection of target pathogens in fungal cultures. The ability of the diagnostic to detect target DNA in fungal cultures suspended in sterile water was examined. Representative isolates of target and nontarget species were grown for 7 to 10 days on half-strength potato dextrose agar amended with $200 \mathrm{ppm}$ streptomycin (sPDA) and incubated at room temperature under black light. Four $0.5-\mathrm{cm}^{3}$ plugs of sPDA of each fungal isolate were added to microfuge tubes containing $1 \mathrm{ml}$ sterile distilled water (sd water) and vigorously shaken to disperse the fungal conidia and mycelia into suspension; $1 \mu l$ of the latter suspension was used as the DNA template in each reaction sample, with one sample containing $1 \mu \mathrm{l}$ of RNase-free water as the template-free negative control. Some microfuge tubes contained two isolates to represent mixed cultures, with three $0.5-\mathrm{cm}^{3}$ plugs of sPDA of each fungal isolate in the tube (Table 3). The LAMP temperature conditions for species-specific diagnostics were set to $67^{\circ} \mathrm{C}$ isothermal amplification for $30 \mathrm{~min}$ followed by 95 to $80^{\circ} \mathrm{C}$ annealing and termination at $0.5^{\circ} \mathrm{C} / \mathrm{s}$. This was repeated for the $\mathrm{Dac}$ tylonectria genus-wide assay with an additional isothermal amplification temperature of $69^{\circ} \mathrm{C}$.

Table 1. List of primer sequences for each loop-mediated isothermal amplification (LAMP) assay ${ }^{z}$

\begin{tabular}{ll}
\hline Target and LAMP primer & \multicolumn{1}{c}{ Primer sequence } \\
\hline Calonectria ilicicola & \\
F3 & $5^{\prime}$-TGTTGCTGCCCCTGAGCG-3' \\
B3 & $5^{\prime}$-GTTACCCTGATCGCGAATGT-3' \\
FIP & $5^{\prime}$-AGTCAGCAACCTTGTCCTCCGACCGGTTCCGACCGCTTC-3' \\
BIP & $5^{\prime}$-CTTCTCAATTCTAGCTCCACCCCAGGGCAGTTTTTGG-3' \\
F Loop & $5^{\prime}$-TCGTCGAGCTTTGTTGTTGTC-3' \\
B Loop & $5^{\prime}$-GTCAGTGCGTAAGTGATCATTCC-3' \\
Dactylonectria macrodidyma & \\
F3 & \\
B3 & $5^{\prime}$-GTCCACTGGTGGCAAGG-3' \\
FIP & $5^{\prime}$-CACGGAGAGCGACGGTA-3' \\
BIP & $5^{\prime}$-GTATGGCGATGCATTTTTGATCTTCCAAGGCTGGTGAGT-3' \\
F Loop & $5^{\prime}$-ACCTTAACCATCAACAGCCCGCGTAGCGGTGAGGCTTCTTG-3' \\
B Loop & $5^{\prime}$-CGCGACGTGTCAAGTAAATGG-3' \\
Dactylonectria spp. & $5^{\prime}$-GCCCCCTCTACCGGTGGTGT-3' \\
F3 & \\
B3 & \\
FIP & $5^{\prime}$-TCCAAGGCTGGTGAGTCTCG-3' \\
BIP & $5^{\prime}$-ACTCACGAGACGCTGGAA-3' \\
F Loop & $5^{\prime}$-GCTCTTGCGGGCTGTTGATATTTACTTGACGCGTCGC-3' \\
B Loop & $5^{\prime}$-TCAAGAAGCCTCACCGCTACATGAGGAGCTCGGTCGACT-3' \\
\hline
\end{tabular}

${ }^{\mathrm{z}}$ BIP, backward inner primer; B Loop, backward loop; FIP, forward inner primer; F Loop, forward loop. 
Table 2. Experiment 3-screening DNA from multiple isolates to confirm loop-mediated isothermal amplification (LAMP) specificity of optimized primer sets and isothermal conditions for detection of target species Calonectria ilicicola, Dactylonectria macrodidyma, and Dactylonectria spp. using pure fungal DNA extracts as templates ${ }^{\mathrm{z}}$

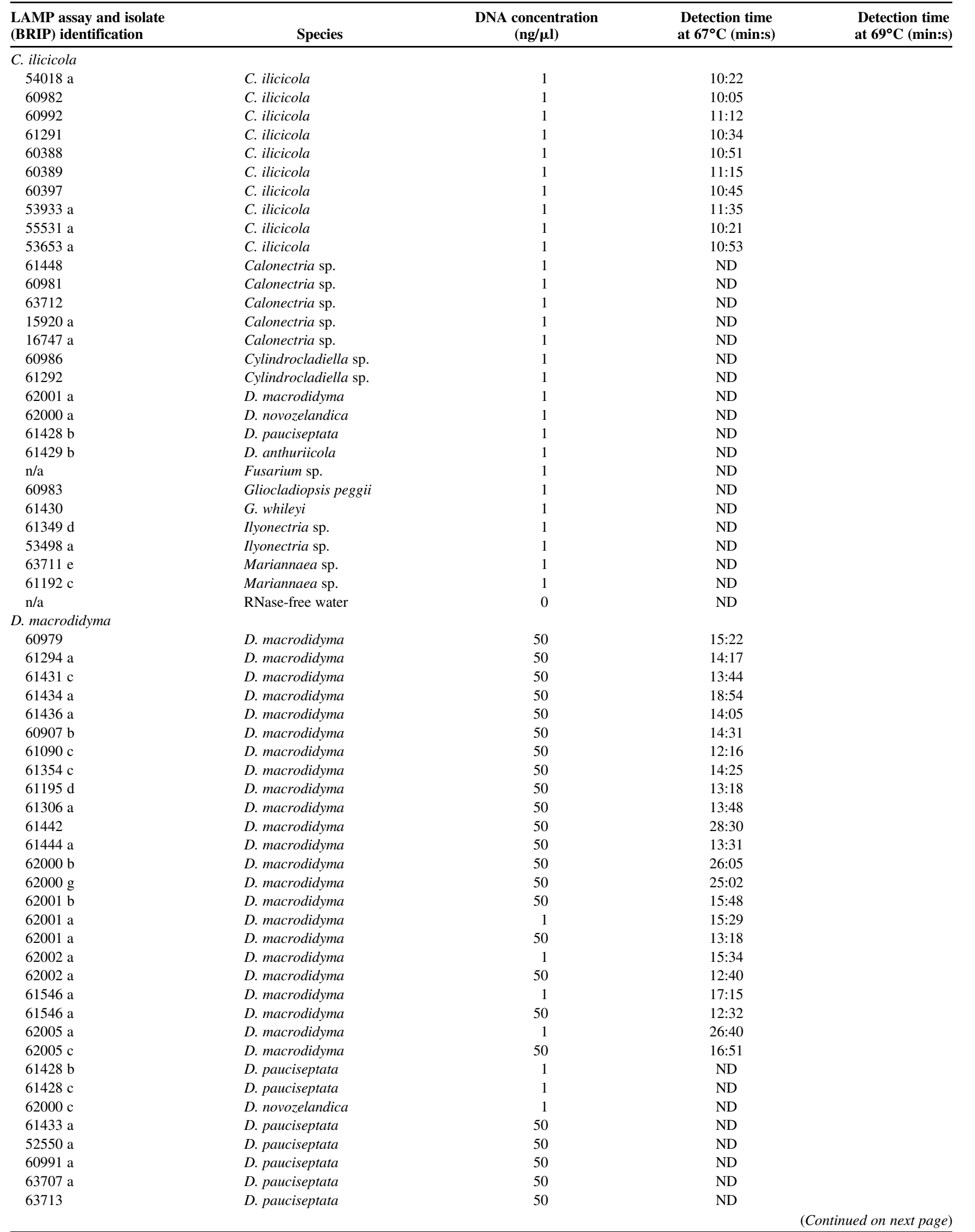

\footnotetext{
${ }^{\text {z }}$ BRIP, Biosecurity Queensland Plant Pathology Herbarium; FP, false positive as indicated by detection of a nontarget species in $<30$ min or an inconsistent or
} absent annealing curve; ND, not detected; $\mathrm{n} / \mathrm{a}$, not applicable. 
Table 2. (Continued from previous page)

\begin{tabular}{|c|c|c|c|c|}
\hline $\begin{array}{l}\text { LAMP assay and isolate } \\
\text { (BRIP) identification }\end{array}$ & Species & $\begin{array}{l}\text { DNA concentration } \\
(\mathrm{ng} / \mu \mathrm{l})\end{array}$ & $\begin{array}{l}\text { Detection time } \\
\text { at } 67^{\circ} \mathrm{C}(\mathrm{min}: \mathrm{s})\end{array}$ & $\begin{array}{l}\text { Detection time } \\
\text { at } 69^{\circ} \mathrm{C} \text { (min:s) }\end{array}$ \\
\hline $62000 \mathrm{~d}$ & D. novozelandica & 1 & ND & \\
\hline $61429 b$ & D. anthuriicola & 50 & ND & \\
\hline $61195 \mathrm{~b}$ & D. vitis & 50 & ND & \\
\hline $63708 \mathrm{~b}$ & D. vitis & 50 & ND & \\
\hline $61263 \mathrm{~g}$ & D. vitis & 50 & ND & \\
\hline $54018 \mathrm{a}$ & C. ilicicola & 1 & ND & \\
\hline 60986 & Cylindrocladiella sp. & 1 & ND & \\
\hline $\mathrm{n} / \mathrm{a}$ & Fusarium sp. & 1 & ND & \\
\hline 60983 & G. peggii & 1 & ND & \\
\hline $61349 \mathrm{a}$ & G. forsbergii & 50 & ND & \\
\hline $53498 \mathrm{a}$ & Ilyonectria sp. & 1 & ND & \\
\hline $61192 \mathrm{c}$ & Mariannaea sp. & 1 & ND & \\
\hline $\mathrm{n} / \mathrm{a}$ & Phytophthora cinnamomi & $>50$ & ND & \\
\hline $\mathrm{n} / \mathrm{a}$ & RNase-free water & 0 & ND & \\
\hline \multicolumn{5}{|l|}{ Dactylonectria spp. } \\
\hline 60979 & D. macrodidyma & 50 & $10: 15$ & 9:00 \\
\hline $61349 \mathrm{e}$ & D. macrodidyma & 50 & $7: 30$ & $7: 45$ \\
\hline $61431 \mathrm{c}$ & D. macrodidyma & 50 & $7: 30$ & $7: 15$ \\
\hline $61434 \mathrm{a}$ & D. macrodidyma & 50 & $11: 45$ & $11: 30$ \\
\hline $61436 \mathrm{a}$ & D. macrodidyma & 50 & $7: 30$ & $7: 15$ \\
\hline $60907 \mathrm{~b}$ & D. macrodidyma & 50 & $8: 45$ & $8: 15$ \\
\hline $61090 \mathrm{c}$ & D. macrodidyma & 50 & $7: 00$ & 7:00 \\
\hline $61354 \mathrm{c}$ & D. macrodidyma & 50 & $8: 00$ & $8: 00$ \\
\hline $61195 \mathrm{~d}$ & D. macrodidyma & 50 & $7: 30$ & $7: 15$ \\
\hline $61306 \mathrm{a}$ & D. macrodidyma & 50 & 8:00 & $8: 00$ \\
\hline 61442 & D. macrodidyma & 50 & $9: 45$ & 9:00 \\
\hline $61444 \mathrm{a}$ & D. macrodidyma & 50 & 8:00 & $7: 45$ \\
\hline $62000 \mathrm{~b}$ & D. macrodidyma & 50 & $12: 45$ & $11: 30$ \\
\hline $62000 \mathrm{~g}$ & D. macrodidyma & 50 & $13: 15$ & $12: 30$ \\
\hline $\mathrm{n} / \mathrm{a}$ & RNase-free water & 0 & ND & ND \\
\hline $62001 \mathrm{~b}$ & D. macrodidyma & 50 & $11: 00$ & $10: 30$ \\
\hline $62001 \mathrm{a}$ & D. macrodidyma & 50 & $6: 15$ & $7: 00$ \\
\hline $62002 \mathrm{a}$ & D. macrodidyma & 50 & $6: 00$ & $6: 45$ \\
\hline $61546 \mathrm{a}$ & D. macrodidyma & 50 & $6: 00$ & 7:00 \\
\hline $62005 \mathrm{c}$ & D. macrodidyma & 50 & $7: 15$ & $8: 45$ \\
\hline $61295 \mathrm{~d}$ & D. pauciseptata & 50 & $12: 15$ & $12: 00$ \\
\hline $61428 \mathrm{~b}$ & D. pauciseptata & 50 & $12: 30$ & $13: 15$ \\
\hline $61428 \mathrm{c}$ & D. pauciseptata & 50 & $13: 30$ & $14: 00$ \\
\hline $61428 d$ & D. pauciseptata & 50 & $12: 15$ & $12: 30$ \\
\hline $61433 \mathrm{a}$ & D. pauciseptata & 50 & $13: 30$ & $13: 45$ \\
\hline $52550 \mathrm{a}$ & D. pauciseptata & 50 & $17: 30$ & $16: 30$ \\
\hline $60991 \mathrm{a}$ & D. pauciseptata & 50 & $11: 30$ & $11: 30$ \\
\hline $63707 \mathrm{a}$ & D. pauciseptata & 50 & $13: 30$ & $13: 15$ \\
\hline 63713 & D. pauciseptata & 50 & $13: 15$ & $13: 15$ \\
\hline $62000 \mathrm{a}$ & D. novozelandica & 50 & 11:00 & $12: 30$ \\
\hline $\mathrm{n} / \mathrm{a}$ & RNase-free water & 0 & $26: 30 \mathrm{FP}$ & ND \\
\hline $62000 \mathrm{c}$ & D. novozelandica & 50 & $12: 00$ & 13:00 \\
\hline $62000 \mathrm{~d}$ & D. novozelandica & 50 & $11: 30$ & $16: 00$ \\
\hline 60985 & D. anthuriicola & 50 & $11: 15$ & $15: 15$ \\
\hline $61429 \mathrm{~b}$ & D. anthuriicola & 50 & 11:00 & $15: 00$ \\
\hline $61306 \mathrm{~b}$ & D. anthuriicola & 50 & $11: 45$ & $15: 15$ \\
\hline $61437 \mathrm{~b}$ & D. anthuriicola & 50 & $9: 15$ & $15: 30$ \\
\hline $61195 \mathrm{~b}$ & D. vitis & 50 & 10:00 & $12: 00$ \\
\hline $63708 \mathrm{~b}$ & D. vitis & 50 & 9:00 & $12: 15$ \\
\hline $61263 \mathrm{f}$ & D. vitis & 50 & $10: 30$ & $11: 45$ \\
\hline $61263 \mathrm{~g}$ & D. vitis & 50 & $6: 15$ & $12: 45$ \\
\hline $61352 \mathrm{c}$ & D. macrodidyma & 50 & $9: 15$ & 8:00 \\
\hline $61354 \mathrm{c}$ & D. macrodidyma & 50 & 8:00 & $10: 30$ \\
\hline 53498 a & Ilyonectria sp. & 50 & $29: 15 \mathrm{FP}$ & ND \\
\hline 60980 & Ilyonectria sp. & 50 & $28: 30 \mathrm{FP}$ & ND \\
\hline $61349 \mathrm{~d}$ & Ilyonectria sp. & 50 & ND & ND \\
\hline $\mathrm{n} / \mathrm{a}$ & RNase-free water & 0 & ND & ND \\
\hline $61546 \mathrm{a}$ & D. macrodidyma & 50 & $6: 15$ & $7: 15$ \\
\hline $61263 \mathrm{f}$ & D. vitis & 50 & $9: 15$ & 11:00 \\
\hline $61294 \mathrm{a}$ & D. macrodidyma & 50 & $7: 30$ & 9:00 \\
\hline \multirow[t]{2}{*}{$54018 \mathrm{a}$} & C. ilicicola & 50 & 21:00 FP & ND \\
\hline & & & & led on next page) \\
\hline
\end{tabular}


Experiment 5: Validation of the LAMP diagnostic for detection of target pathogens in inoculated necrotic avocado roots. Experiment 5 tested the LAMP diagnostic for its ability to detect the target species directly in avocado root tissue. Twenty-three 6-month-old avocado cultivar Reed seedlings were inoculated by amending the potting soil with $\sim 250 \mathrm{ml}$ sand:bran:water media mixed with vermiculite (grade 3 ), prepared as described in Parkinson et al. (2017), and colonized with $C$. ilicicola, D. macrodidyma, D. anthuriicola, D. novozelandica, D. pauciseptata, D. vitis, or a mixture of equal parts (percentage volume:volume) $C$. ilicicola and one species of the listed Dactylonectria species. The roots of a healthy, uninoculated 6-month-old Reed seedling were included as a negative control. The plants were maintained in the glasshouse at 22 to $24^{\circ} \mathrm{C}$ during the day and $18^{\circ} \mathrm{C}$ at night. At 7 weeks post inoculation, the plants were uprooted and assessed for root disease, and necrotic or healthy avocado roots were collected for use in the LAMP assay.

The LAMP assays were modified to include a DNA extraction step using the OptiGene Plant DNA Extraction Kit (GeneWorks Pty Ltd) for detection with avocado root tissue. For each LAMP assay test sample, necrotic avocado root pieces were sliced into two $1.5-\mathrm{cm}$ sections and added to a 10-ml tube containing a large steel ball bearing from the kit. Each test sample was diluted with three $1.5-\mathrm{cm}$ sections of healthy, uninoculated avocado root pieces. Fungal DNA was extracted following the manufacturer's instructions; $1 \mathrm{ml}$ Lysis Buffer was added to each tube containing root tissue, and the tubes were shaken vigorously by hand for $1 \mathrm{~min}$ to macerate the tissue. Approximately $10 \mu \mathrm{l}$ of crude DNA extract was transferred by sterile loop into $1 \mathrm{ml}$ dilution buffer, and the solution was mixed by inversion. Five $\mu l$ of diluted crude extract was used as the DNA template in the LAMP reaction.

The LAMP reaction master mix was modified to suit detection with avocado root tissue. The reaction mixture for each test sample contained a total volume of $25 \mu \mathrm{l}$ made up of $15 \mu \mathrm{l}$ OptiGene Isothermal Master Mix (GeneWorks Pty Ltd), $5 \mu l$ working primer mixture as listed above, and $5 \mu \mathrm{l}$ DNA template. The isothermal temperature conditions for detecting C. ilicicola and D. macrodidyma were set to $67^{\circ} \mathrm{C}$ isothermal amplification for $40 \mathrm{~min}$ (Table 4 ) followed by 95 to $80^{\circ} \mathrm{C}$ annealing and termination at $0.5^{\circ} \mathrm{C} / \mathrm{s}$. This was repeated for the Dactylonectria genus-wide assay with an additional isothermal temperature of $69^{\circ} \mathrm{C}$ for comparison (Table 4). Each LAMP assay was conducted twice, with freshly sampled roots for each diagnostic run.

\section{Results}

Sensitivity and specificity of LAMP diagnostic, chosen primer sets, and optimization of isothermal conditions. Experiment 1: Initial sensitivity and specificity testing and optimizing isothermal conditions. The results of experiment 1 are listed in Supplementary Table S2. In the initial sensitivity and specificity tests, the F3, B3, FIP, and BIP primers designed for detecting C. ilicicola were sensitive and specific to the target species at DNA concentrations as low as $1 \mathrm{pg} / \mu \mathrm{l}$. Isothermal amplification temperatures were compared, and the optimal temperature was found to be $67^{\circ} \mathrm{C}$, enabling detection of $1 \mathrm{ng} / \mu \mathrm{l}$ DNA at $17 \mathrm{~min}$ and $41 \mathrm{~s}$, with the detection slowing down as the temperature decreased. Isothermal amplification temperature of $67^{\circ} \mathrm{C}$ was selected for use in all additional experiments for detecting $C$. ilicicola. In terms of sensitivity, $C$. ilicicola could be detected at DNA concentrations of $1 \mathrm{pg} / \mu \mathrm{l}$; however, the speed of detection varied and was slower than at higher concentrations, with detection at $24 \mathrm{~min}$ and $56 \mathrm{~s}$ at $65^{\circ} \mathrm{C}$ and detection at $27 \mathrm{~min}$ and $24 \mathrm{~s}$ at $67^{\circ} \mathrm{C}$. In all tests, detection was slowest at isothermal amplification temperature of $63^{\circ} \mathrm{C}$.

False positive detection in any sample was determined by an annealing curve not consistent in peak height or position with the curve representing the positive control for detection, an absent annealing curve, or an absent annealing and terminating temperature record. Across all assays, reliable positive detection occurred in $<30 \mathrm{~min}$, and any detection after $30 \mathrm{~min}$ was considered nondetection.

The F3, B3, FIP, and BIP primers designed for detecting D. macrodidyma were sensitive and specific to the target species at DNA concentrations of $1 \mathrm{ng} / \mu \mathrm{l}$ but detected after the 30-min threshold for reliability. The detection of the target species facilitated by these primers was slower and less sensitive than in the tests with $C$. ilicicola primers. Sensitivity was not demonstrated at DNA concentrations $<0.1 \mathrm{ng} / \mu \mathrm{l}$; therefore, no additional isothermal temperatures

Table 2. (Continued from previous page)

\begin{tabular}{|c|c|c|c|c|}
\hline $\begin{array}{l}\text { LAMP assay and isolate } \\
\text { (BRIP) identification }\end{array}$ & Species & $\begin{array}{l}\text { DNA concentration } \\
(\mathrm{ng} / \mu \mathrm{l})\end{array}$ & $\begin{array}{l}\text { Detection time } \\
\text { at } 67^{\circ} \mathrm{C} \text { (min:s) }\end{array}$ & $\begin{array}{l}\text { Detection time } \\
\text { at } 69^{\circ} \mathrm{C} \text { (min:s) }\end{array}$ \\
\hline 60982 & C. ilicicola & 50 & $29: 15 \mathrm{FP}$ & ND \\
\hline 61448 & Calonectria sp. & 50 & 24:00 FP & ND \\
\hline 60981 & Calonectria sp. & 50 & $29: 15 \mathrm{FP}$ & ND \\
\hline 60986 & Cylindrocladiella sp. & 50 & ND & ND \\
\hline 61292 & Cylindrocladiella sp. & 50 & ND & ND \\
\hline $63711 \mathrm{e}$ & Mariannaea sp. & 50 & $29: 15 \mathrm{FP}$ & ND \\
\hline $61192 \mathrm{c}$ & Mariannaea sp. & 50 & ND & ND \\
\hline 60983 & G. peggii & 50 & 21:30 FP & ND \\
\hline 61430 & G. whileyi & 50 & $21: 45 \mathrm{FP}$ & ND \\
\hline $63711 \mathrm{f}$ & Ilyonectria sp. & 50 & 20:30 FP & 17:00 FP \\
\hline $61090 \mathrm{a}$ & Ilyonectria sp. & 50 & $25: 15 \mathrm{FP}$ & ND \\
\hline $\mathrm{n} / \mathrm{a}$ & RNase-free water & 0 & $29: 15 \mathrm{FP}$ & ND \\
\hline $61546 a$ & D. macrodidyma & 50 & $9: 15$ & $7: 30$ \\
\hline $60991 \mathrm{a}$ & D. pauciseptata & 50 & $12: 00$ & $12: 30$ \\
\hline $61432 b$ & Ilyonectria sp. & 50 & $27: 45 \mathrm{FP}$ & ND \\
\hline $61090 \mathrm{a}$ & Ilyonectria sp. & 50 & $25: 15 \mathrm{FP}$ & 28:30 FP \\
\hline $63711 \mathrm{f}$ & Ilyonectria sp. & 50 & $9: 45 \mathrm{FP}$ & $15: 30 \mathrm{FP}$ \\
\hline $63711 \mathrm{~g}$ & Ilyonectria sp. & 50 & 18:00 FP & $17: 30 \mathrm{FP}$ \\
\hline $61546 \mathrm{i}$ & Ilyonectria sp. & 50 & ND & ND \\
\hline $61194 \mathrm{a}$ & Ilyonectria sp. & 50 & $25: 30 \mathrm{FP}$ & ND \\
\hline $61435 \mathrm{c}$ & Ilyonectria sp. & 50 & 29:00 FP & ND \\
\hline $62004 \mathrm{~b}$ & Ilyonectria sp. & 50 & ND & ND \\
\hline 60989 & Ilyonectria sp. & 50 & ND & ND \\
\hline 61443 & Ilyonectria sp. & 50 & $29: 15$ FP & ND \\
\hline 61293 & Ilyonectria sp. & 50 & ND & ND \\
\hline 53652 a & Ilyonectria sp. & 50 & $29: 15 \mathrm{FP}$ & ND \\
\hline $61303 \mathrm{~d}$ & Ilyonectria sp. & 50 & $29: 15 \mathrm{FP}$ & ND \\
\hline $\mathrm{n} / \mathrm{a}$ & RNase-free water & 0 & ND & ND \\
\hline
\end{tabular}


were tested for target species D. macrodidyma. Tests with loop primers in experiment 2 aimed to improve the sensitivity, specificity, and detection speed.

Initial specificity testing of F3, B3, FIP, and BIP primers for detecting Dactylonectria spp. showed detection between $16 \mathrm{~min}$ and $15 \mathrm{~s}$ and $25 \mathrm{~min}$ and nondetection from $30 \mathrm{~min}$; 13 of 14 $(\sim 93 \%)$ Dactylonectria isolates were detected.

Experiment 2: Testing loop primers for improved detection time, sensitivity, and specificity. In experiment 2 , combinations of loop primers were tested with the four F3, B3, FIP, and BIP primers for an improved speed of detection, sensitivity, and specificity for $C$. ilicicola, D. macrodidyma, or Dactylonectria spp. The results of experiment 2 are listed in Supplementary Table S3.

The B Loop primer in combination with the four F3, B3, FIP, and BIP primers performed the best, with the highest sensitivity and fastest detection of $C$. ilicicola at low DNA concentrations of $1 \mathrm{pg} / \mu \mathrm{l}$ compared with the other loop primer combinations. The F Loop primer enabled faster detection at DNA concentrations of $1 \mathrm{ng} / \mu \mathrm{l}$, detecting the DNA $1 \mathrm{~min}$ and $10 \mathrm{~s}$ faster than the B Loop primer. However, at DNA concentrations $<0.01 \mathrm{ng} / \mu \mathrm{l}$, detection with F Loop was slower than the detection with B Loop. Therefore, F Loop and B Loop individually improved detection time and had roughly equal sensitivity; however, B Loop was slightly faster at lower DNA concentrations than F Loop. When combined, the F Loop and B Loop primers enabled the fastest detection of DNA in 5 min and $51 \mathrm{~s}$ to $7 \mathrm{~min}$ and $5 \mathrm{~s}$ at concentrations of 1 to $0.1 \mathrm{ng} / \mu \mathrm{l}$. However, sensitivity was reduced by using both loop primers, because DNA concentrations of $0.01 \mathrm{ng} / \mu \mathrm{l}$ were detected at a similar time to that with $\mathrm{B}$ Loop primers alone, and there was no detection at concentrations $<0.01 \mathrm{ng} / \mu \mathrm{l}$. Therefore, the B Loop primer was selected for use in the LAMP diagnostic for $C$. ilicicola, and it was tested in subsequent experiments.

Table 3. Experiment 4-testing optimized primer sets and isothermal conditions for specificity in detection of target species Calonectria ilicicola, Dactylonectria macrodidyma, and Dactylonectria spp. using crude extracts from a suspension of fungal cultures in sterile distilled water ${ }^{\mathrm{z}}$

\begin{tabular}{|c|c|c|c|c|}
\hline $\begin{array}{l}\text { LAMP assay and isolate } \\
\text { (BRIP) identification }\end{array}$ & Species & $\begin{array}{l}\text { DNA concentration } \\
(\mathrm{ng} / \mu \mathrm{l})\end{array}$ & $\begin{array}{l}\text { Detection time } \\
\text { at } 67^{\circ} \mathrm{C}(\mathrm{min}: \mathrm{s})\end{array}$ & $\begin{array}{r}\text { Detection time } \\
\text { at } 69^{\circ} \mathrm{C}(\mathrm{min}: \mathrm{s})\end{array}$ \\
\hline \multicolumn{5}{|l|}{$\begin{array}{l}\text { C. ilicicola } \\
\text { s. }\end{array}$} \\
\hline 54018 a & C. ilicicola & Undetermined & $15: 15$ & \\
\hline 60982 & C. ilicicola & Undetermined & $15: 00$ & \\
\hline 60992 & C. ilicicola & Undetermined & $15: 48$ & \\
\hline 61291 & C. ilicicola & Undetermined & $16: 10$ & \\
\hline 61291 & C. ilicicola & Undetermined & $17: 28$ & \\
\hline 60389 & C. ilicicola & Undetermined & $29: 15$ & \\
\hline $53933 \mathrm{a}$ & C. ilicicola & Undetermined & $23: 16$ & \\
\hline 60981 & Calonectria sp. & Undetermined & ND & \\
\hline $54018 a+60981$ & C. ilicicola + Calonectria sp. & Undetermined & ND & \\
\hline $60982+60981$ & C. ilicicola + Calonectria sp. & Undetermined & $24: 05$ & \\
\hline $61291+60981$ & C. ilicicola + Calonectria sp. & Undetermined & $17: 49$ & \\
\hline $\mathrm{n} / \mathrm{a}$ & Ilyonectria sp. fungal culture & Undetermined & ND & \\
\hline $\mathrm{n} / \mathrm{a}$ & RNase-free water & 0 & ND & \\
\hline \multicolumn{5}{|l|}{ D. macrodidyma } \\
\hline $61294 \mathrm{a}$ & D. macrodidyma & Undetermined & $18: 16$ & \\
\hline $61294 \mathrm{a}$ & D. macrodidyma & Undetermined & $17: 27$ & \\
\hline $61349 \mathrm{e}$ & D. macrodidyma & Undetermined & $16: 35$ & \\
\hline $61349 \mathrm{e}$ & D. macrodidyma & Undetermined & $22: 38$ & \\
\hline $62001 \mathrm{~b}$ & D. macrodidyma & Undetermined & $16: 28$ & \\
\hline $62001 \mathrm{~b}$ & D. macrodidyma & Undetermined & $25: 14$ & \\
\hline $61428 \mathrm{~d}$ & D. pauciseptata & Undetermined & ND & \\
\hline $62000 \mathrm{~d}$ & D. novozelandica & Undetermined & ND & \\
\hline 60985 & D. anthuriicola & Undetermined & ND & \\
\hline $61294 a+62000 d$ & D. macrodidyma $+D$. novozelandica & Undetermined & $16: 13$ & \\
\hline $61349 e+62000 d$ & D. macrodidyma $+D$. novozelandica & Undetermined & $29: 21$ & \\
\hline $62001 b+62000 d$ & D. macrodidyma + D. novozelandica & Undetermined & $20: 41$ & \\
\hline $61428 d+62000 d$ & D. pauciseptata $+D$. novozelandica & Undetermined & ND & \\
\hline $\mathrm{n} / \mathrm{a}$ & Ilyonectria sp. fungal culture & Undetermined & ND & \\
\hline $\mathrm{n} / \mathrm{a}$ & RNase-free water & 0 & ND & \\
\hline \multicolumn{5}{|l|}{ Dactylonectria spp. } \\
\hline 61546 a & D. macrodidyma & Undetermined & $6: 30$ & $7: 15$ \\
\hline $61349 \mathrm{e}$ & D. macrodidyma & Undetermined & 17:00 & $12: 15$ \\
\hline $61429 \mathrm{~b}$ & D. macrodidyma & Undetermined & $20: 15$ & 19:00 \\
\hline 60985 & D. anthuriicola & Undetermined & $17: 00$ & $16: 00$ \\
\hline $62000 \mathrm{~d}$ & D. novozelandica & Undetermined & $13: 15$ & $14: 15$ \\
\hline $61428 d$ & D. pauciseptata & Undetermined & $20: 30$ & $17: 15$ \\
\hline $63708 \mathrm{~b}$ & D. vitis & Undetermined & $13: 15$ & $14: 45$ \\
\hline $61349 \mathrm{e}+54018 a$ & D. macrodidyma + C. ilicicola & Undetermined & $14: 15$ & $10: 30$ \\
\hline $61429 b+54018 a$ & D. macrodidyma + C. ilicicola & Undetermined & $19: 45$ & 23:00 \\
\hline $60985+54018 a$ & D. anthuriicola + C. ilicicola & Undetermined & $16: 45$ & $18: 15$ \\
\hline $62000 d+54018 a$ & D. novozelandica $+C$. ilicicola & Undetermined & $25: 15$ & $18: 30$ \\
\hline $61428 d+54018 a$ & D. pauciseptata $+C$. ilicicola & Undetermined & $16: 30$ & $21: 45$ \\
\hline $63708 b+54018 a$ & D. vitis $+C$. ilicicola & Undetermined & $20: 15$ & 20:00 \\
\hline $54018 \mathrm{a}$ & C. ilicicola & Undetermined & $25: 15 \mathrm{FP}$ & ND \\
\hline $\mathrm{n} / \mathrm{a}$ & RNase-free water & 0 & ND & ND \\
\hline
\end{tabular}

${ }^{\mathrm{z}}$ BRIP, Biosecurity Queensland Plant Pathology Herbarium; FP, false positive as indicated by detection of a nontarget species in $<30$ min or an inconsistent or absent annealing curve; LAMP, loop-mediated isothermal amplification; ND, not detected; n/a, not applicable. 
The initial tests with the loop primers and four LAMP primers F3, $\mathrm{B} 3$, FIP, and BIP for the D. macrodidyma diagnostic were performed at an isothermal amplification temperature of $65^{\circ} \mathrm{C}$, and loop primer combinations were compared to find the optimal primer combination. Including loop primers with the four standard LAMP primers improved sensitivity and detection speed compared with in experiment 1, which had no loop primers. Furthermore, LAMP primers with the B Loop primer were the most sensitive, detecting target DNA at $0.01 \mathrm{ng} / \mu \mathrm{l}$ within $17 \mathrm{~min}$ and $7 \mathrm{~s}$. The F Loop primer enabled the fastest detection at $14 \mathrm{~min}$ and $51 \mathrm{~s}$ for concentrations of $1 \mathrm{ng} / \mu \mathrm{l}$ compared with $16 \mathrm{~min}$ and $4 \mathrm{~s}$ for B Loop and $18 \mathrm{~min}$ and $2 \mathrm{~s}$ for $\mathrm{F}$ Loop and B Loop combined. However, despite faster detection, use of the F Loop primer alone resulted in reduced sensitivity, with DNA concentrations detected at concentrations $>0.01 \mathrm{ng} / \mu \mathrm{l}$ compared with successful detection at $<0.01 \mathrm{ng} / \mu \mathrm{l}$ with use of the B Loop primer. Use of both loop primers combined resulted in the slowest detection speed and the lowest specificity, with detection occurring between 18 and $19 \mathrm{~min}$ and sensitivity to $0.1 \mathrm{ng} / \mu \mathrm{l}$.

Although sensitivity and detection time were improved with introduction of B Loop primers, time seems to be an inhibiting factor in maintaining specificity to the target species. Across all loop primer combinations tested at $65^{\circ} \mathrm{C}$, the nontarget species $D$. novozelandica, a close relative of $D$. macrodidyma, was detected within 29 to
55 min, with the F Loop primer detecting nontarget species the fastest and both loop primers combined detecting nontargets the slowest. It was, therefore, concluded that the success of target species specificity is dependent on time and the loop primers used. The optimal isothermal amplification time for this diagnostic design was $30 \mathrm{~min}$ to maintain target species specificity. However, the B Loop primer was found to be the most appropriate primer to satisfy the full criteria to a time cutoff for specificity, high sensitivity, and adequate detection speed. Therefore, the B Loop primer was chosen for subsequent LAMP diagnostic tests.

Additional tests in experiment 2 used the B Loop primer and compared the efficacy of the diagnostic between isothermal amplification temperatures of 63,65 , and $67^{\circ} \mathrm{C}$. At DNA concentrations of $1 \mathrm{ng} / \mu \mathrm{l}$, detection was fastest at $14 \mathrm{~min}$ and $37 \mathrm{~s}$, with an isothermal temperature of $67^{\circ} \mathrm{C}$, and it slowed to just $>16$ min at 63 and $65^{\circ} \mathrm{C}$. Although the greatest sensitivity of detection (at $1 \mathrm{pg} / \mu \mathrm{l}$ DNA) was observed with isothermal temperature of $65^{\circ} \mathrm{C}$, the speed of detection was $53 \mathrm{~min}$ and $20 \mathrm{~s}$, which was beyond the previously determined optimal amplification time of $30 \mathrm{~min}$. At DNA concentrations of $0.01 \mathrm{ng} / \mu \mathrm{l}$, an isothermal temperature of $67^{\circ} \mathrm{C}$ performed detection faster than at $65^{\circ} \mathrm{C}$. Therefore, the optimal isothermal temperature of $67^{\circ} \mathrm{C}$ for $D$. macrodidyma detection was used in all additional experiments.

Table 4. Experiment 5-validation of the loop-mediated isothermal amplification (LAMP) diagnostic for detection of target pathogens Calonectria ilicicola, Dactylonectria macrodidyma, and Dactylonectria spp. in inoculated necrotic avocado roots ${ }^{\mathrm{z}}$

\begin{tabular}{|c|c|c|c|c|c|c|c|c|c|c|}
\hline \multirow[b]{2}{*}{$\begin{array}{l}\text { Plant } \\
\text { number }\end{array}$} & \multirow[b]{2}{*}{$\begin{array}{l}\text { Isolate (BRIP) } \\
\text { identification }\end{array}$} & \multirow[b]{2}{*}{ Inoculum } & \multicolumn{2}{|c|}{ Detection of $C$. ilicicola } & \multicolumn{2}{|c|}{$\begin{array}{c}\text { Detection of } \\
\text { D. macrodidyma }\end{array}$} & \multicolumn{4}{|c|}{ Detection of Dactylonectria spp. } \\
\hline & & & $\begin{array}{l}\text { Trial 1 at } \\
67^{\circ} \mathrm{C} \text { (min:s) }\end{array}$ & $\begin{array}{l}\text { Trial 2 at } \\
67^{\circ} \mathrm{C} \text { (min:s) }\end{array}$ & $\begin{array}{c}\text { Trial 1 at } \\
67^{\circ} \mathrm{C} \text { (min:s) }\end{array}$ & $\begin{array}{l}\text { Trial 2 at } \\
67^{\circ} \mathrm{C} \text { (min:s) }\end{array}$ & $\begin{array}{l}\text { Trial 1 at } \\
67^{\circ} \mathrm{C} \text { (min:s) }\end{array}$ & $\begin{array}{c}\text { Trial 2 at } \\
67^{\circ} \mathrm{C} \text { (min:s) }\end{array}$ & $\begin{array}{c}\text { Trial 1 at } \\
69^{\circ} \mathrm{C} \text { (min:s) }\end{array}$ & $\begin{array}{c}\text { Trial 2 at } \\
69^{\circ} \mathrm{C} \text { (min:s) }\end{array}$ \\
\hline $\mathrm{n} / \mathrm{a}$ & 62001 a & $\begin{array}{l}\text { D. macrodidyma (50 } \\
\mathrm{ng} / \mu \mathrm{l} \text { DNA) }\end{array}$ & ND & ND & $7: 45$ & $8: 00$ & $5: 30$ & $5: 15$ & $5: 45$ & $7: 30$ \\
\hline $\mathrm{n} / \mathrm{a}$ & 54018 a & $\begin{array}{l}\text { C. ilicicola }(50 \mathrm{ng} / \mu \mathrm{l} \\
\text { DNA) }\end{array}$ & $7: 45$ & $7: 45$ & ND & ND & ND & 28:00 FP & 36:15 ND & $34: 45$ ND \\
\hline 1 & 60985 & D. anthuriicola & ND & ND & ND & ND & 16:00 & 15:30 & 18:15 & $18: 45$ \\
\hline 2 & 60985 & D. anthuriicola & ND & ND & ND & ND & 15:00 & 13:45 & $22: 45$ & 29:45 \\
\hline 3 & $62000 \mathrm{~d}$ & D. novozelandica & ND & ND & 39:15 ND & ND & $15: 30$ & 39:15 ND & ND & $22: 30$ \\
\hline 4 & $62000 \mathrm{~d}$ & D. novozelandica & ND & ND & ND & ND & $17: 30$ & 19:45 & 39:15 ND & $28: 45$ \\
\hline 5 & $61428 \mathrm{~d}$ & D. pauciseptata & $34: 15 \mathrm{ND}$ & ND & ND & 39:15 ND & 20:00 & $28: 45$ & ND & 29:15 \\
\hline 6 & $61428 \mathrm{~d}$ & D. pauciseptata & ND & ND & ND & ND & 18:15 & 20:00 & $18: 45$ & 39:15 ND \\
\hline 7 & $63708 \mathrm{~b}$ & D. vitis & ND & ND & ND & ND & 20:00 & 15:00 & $20: 45$ & $16: 30$ \\
\hline 8 & $63708 \mathrm{~b}$ & D. vitis & ND & ND & ND & ND & $16: 00$ & $15: 15$ & $17: 30$ & $17: 30$ \\
\hline 9 & $60985+54018 a$ & $\begin{array}{l}\text { D. anthuriicola }+ \\
\text { C. ilicicola }\end{array}$ & 13:00 & $15: 45$ & ND & ND & $17: 15$ & $15: 15$ & $18: 45$ & $30: 45$ ND \\
\hline 10 & $62000 d+54018 a$ & $\begin{array}{l}\text { D. novozelandica }+ \\
\text { C. ilicicola }\end{array}$ & $14: 45$ & $15: 15$ & ND & ND & ND & $20: 30$ & ND & ND \\
\hline 11 & $61428 d+54018 a$ & $\begin{array}{l}\text { D. pauciseptata }+ \\
\text { C. ilicicola }\end{array}$ & $35: 15$ ND & 36:00 ND & ND & ND & $20: 15$ & $16: 15$ & 27:00 FP & ND \\
\hline 12 & $63708 b+54018 a$ & D. vitis + C. ilicicola & $13: 45$ & ND & ND & 39:15 ND & $23: 30$ & $20: 15$ & 31:45 ND & ND \\
\hline 13 & $\mathrm{n} / \mathrm{a}$ & Uninoculated & ND & ND & ND & ND & 30:30 ND & $36: 30 \mathrm{ND}$ & 33:15 ND & 39:15 ND \\
\hline $\mathrm{n} / \mathrm{a}$ & $\mathrm{n} / \mathrm{a}$ & Template free & ND & ND & ND & ND & 30:30 ND & 32:45 ND & 39:15 ND & 39:15 ND \\
\hline $\mathrm{n} / \mathrm{a}$ & 62001 a & $\begin{array}{l}\text { D. macrodidyma (50 } \\
\text { ng/ } \mu \text { l DNA) }\end{array}$ & ND & $36: 45 \mathrm{ND}$ & 8:00 & $8: 00$ & $15: 15$ & $5: 45$ & $7: 45$ & 8:00 \\
\hline $\mathrm{n} / \mathrm{a}$ & 54018 a & $\begin{array}{l}\text { C. ilicicola }(50 \mathrm{ng} / \mu \mathrm{l} \\
\text { DNA) }\end{array}$ & $6: 15$ & $6: 30$ & ND & ND & 20:30 FP & 24:00 FP & 17:45 FP & 39:15 ND \\
\hline 14 & $61349 \mathrm{e}$ & D. macrodidyma & ND & ND & ND & 21:00 & ND & 13:45 & 22:00 & ND \\
\hline 15 & $61349 \mathrm{e}$ & D. macrodidyma & ND & ND & $12: 00$ & $13: 45$ & $10: 45$ & 29:00 FP & 14:00 & $9: 30$ \\
\hline 16 & $61349 e+54018 a$ & $\begin{array}{l}\text { D. macrodidyma }+ \\
\text { C. ilicicola }\end{array}$ & $22: 00$ & $12: 30$ & $24: 45$ & 23:00 & 29:15 FP & 20:00 & $15: 15$ & 28:00 \\
\hline 17 & $61349 e+54018 a$ & $\begin{array}{l}\text { D. macrodidyma }+ \\
\text { C. ilicicola }\end{array}$ & 13:15 & $11: 45$ & $13: 30$ & $18: 45$ & $15: 15$ & $16: 45$ & $16: 30$ & 18:00 \\
\hline 18 & $61349 e+54018 a$ & $\begin{array}{l}\text { D. macrodidyma }+ \\
\text { C. ilicicola }\end{array}$ & $17: 30$ & $15: 15$ & $15: 15$ & 19:00 & ND & $15: 30$ & $18: 45$ & $21: 15$ \\
\hline 19 & $61349 e+54018 a$ & $\begin{array}{l}\text { D. macrodidyma }+ \\
\text { C. ilicicola }\end{array}$ & $16: 15$ & $12: 45$ & $20: 45$ & $16: 15$ & 14:15 & $13: 45$ & 18:00 & 14:00 \\
\hline 20 & $61349 e+54018 a$ & $\begin{array}{l}\text { D. macrodidyma }+ \\
\text { C. ilicicola }\end{array}$ & $27: 15 \mathrm{FP}$ & 15:00 & $25: 30$ & $18: 15$ & ND & 14:15 & 14:00 & 18:00 \\
\hline 21 & $54018 \mathrm{a}$ & C. ilicicola & 17:00 & $14: 30$ & ND & ND & 28:45 FP & 27:45 FP & ND & ND \\
\hline 22 & $54018 \mathrm{a}$ & C. ilicicola & 21:00 & $24: 45$ & ND & ND & $\mathrm{ND}$ & 27:30 FP & 39:15 ND & ND \\
\hline 23 & $54018 \mathrm{a}$ & C. ilicicola & $\mathrm{ND}$ & $16: 15$ & ND & ND & ND & 37:00 ND & $16: 45$ FP & 39:00 ND \\
\hline 24 & $54018 \mathrm{a}$ & C. ilicicola & $12: 30$ & 13:45 & ND & ND & ND & 35:45 ND & ND & ND \\
\hline $\mathrm{n} / \mathrm{a}$ & $\mathrm{n} / \mathrm{a}$ & Template free & ND & ND & ND & ND & 27:15 FP & $38: 15 \mathrm{ND}$ & 39:15 ND & 39:15 ND \\
\hline
\end{tabular}

${ }^{\mathrm{z}}$ BRIP, Biosecurity Queensland Plant Pathology Herbarium; FP, false positive as indicated by detection of a nontarget species in $<30$ min or an inconsistent or absent annealing curve; ND, not detected or nondetection as indicated by detection after $30 \mathrm{~min}$; n/a, not applicable. 
An initial specificity comparison between loop primer combinations was conducted on the Dactylonectria genus-wide assay before testing the assay for sensitivity. Including any combination of the loop primers in the assay improved the success rate of detection, with $100 \%$ of Dactylonectria isolates detected with 21 min compared with $93 \%$ in experiment 1 . Including both loop primers resulted in faster detection of targets by $\sim 2$ min on average compared with using either loop primer alone. All primer combinations resulted in false positive detection of nontarget species and negative controls. Specificity was improved by including both loop primers, with detection of nontarget Ilyonectria sp. (BRIP 53498a) occurring at 44 min compared with 32 min and $15 \mathrm{~s}$ and 37 min and $45 \mathrm{~s}$ with $\mathrm{F}$ and $\mathrm{B}$ Loop primers, respectively. However, because these were detected after $30 \mathrm{~min}$, it was nevertheless considered nondetection rather than true false positive detection.

The full primer set for detecting Dactylonectria spp. underwent sensitivity testing at isothermal amplification temperatures of $67^{\circ} \mathrm{C}$ for $60 \mathrm{~min}$ and subsequently, $69^{\circ} \mathrm{C}$ for $30 \mathrm{~min}$ with representative species from this genus. Two temperatures were tested for improvement in sensitivity. The isothermal amplification time was reduced to $30 \mathrm{~min}$ in the second assay, because nonspecific amplification of template-free samples was found in the first assay at $67^{\circ} \mathrm{C}$ after 30 min. Detection of target samples after this time was, therefore, considered a false positive result. The LAMP assay at $67^{\circ} \mathrm{C}$ for $60 \mathrm{~min}$ demonstrated sensitivity averaging $0.1 \mathrm{ng} / \mu \mathrm{l}$, with $D$. macrodidyma (BRIP 61546a) detection as low as $1 \mathrm{pg} / \mu \mathrm{l}$. The LAMP assay at $69^{\circ} \mathrm{C}$ for $30 \mathrm{~min}$ demonstrated sensitivity averaging $0.1 \mathrm{ng} / \mu \mathrm{l}$, although one isolate (D. anthuriicola BRIP 60985) could not be detected at $<1 \mathrm{ng} / \mu \mathrm{l}$ and another isolate $(D$. macrodidyma BRIP 61546a) was detected at $1 \mathrm{pg} / \mu \mathrm{l}$ but not at $0.01 \mathrm{ng} / \mu \mathrm{l}$. The LAMP assay at $69^{\circ} \mathrm{C}$ for 30 min was then tested with nontarget Ilyonectria isolates in the specificity screening experiment (experiment 3 ) (Table 2)

LAMP diagnostic for detection of target pathogens in DNA samples, fungal cultures, and inoculated necrotic avocado tissue. Experiment 3: Screening DNA samples in isolate collection to confirm $L A M P$ specificity. Experiment 3 confirmed the specificity of the LAMP diagnostic design for detecting C. ilicicola, D. macrodidyma, and Dactylonectria spp. using 1 and $50 \mathrm{ng} / \mu \mathrm{l}$ fungal DNA extracts and fungal mycelia from a representative number of fungal target species, closely related nontarget species, and other fungal genera associated with root rot disease.

The $C$. ilicicola LAMP diagnostic design was confirmed to be specific, detecting the target species within 10 to $11 \mathrm{~min}$ and $30 \mathrm{~s}$ at DNA concentrations of $1 \mathrm{ng} / \mu \mathrm{l}$ (Table 2). None of the other isolates in the genus Calonectria or the tested genera were detected (Table 2).

The $D$. macrodidyma diagnostic was confirmed to be specific, detecting target DNA within $12 \mathrm{~min}$ and $15 \mathrm{~s}$ to $28 \mathrm{~min}$ and $30 \mathrm{~s} \mathrm{(av-}$ eraging 15 to $16 \mathrm{~min}$ ) at concentrations of $50 \mathrm{ng} / \mu \mathrm{l}$. None of the nontarget Dactylonectria spp. (Table 2) or species in the other genera were detected. Some $D$. macrodidyma isolates were tested twice at concentrations of 1 and $50 \mathrm{ng} / \mu \mathrm{l}$ to observe any differences in detection speed (Table 2). The 50-ng/ $\mu$ l DNA templates were detected considerably faster (by $\sim 2$ to $9 \mathrm{~min}$ ) than the 1-ng/ $\mu 1$ DNA templates.

The Dactylonectria genus-wide assay at an isothermal amplification temperature of $67^{\circ} \mathrm{C}$ was demonstrated to amplify all Dactylonectria spp. isolates within 6 to $17 \mathrm{~min}$ and $30 \mathrm{~s}$ (Table 2). However, this assay was also found to amplify nontarget genera between 9 min and $45 \mathrm{~s}$ and $25 \mathrm{~min}$ and $15 \mathrm{~s}$, including one isolate of $C$. ilicicola, Calonectria sp., Gliocladiopsis peggii, G. whileyi, and five isolates of Ilyonectria sp. (Table 2). A number of false positives were also found in nontarget genera detected within $\sim 2$ min and $15 \mathrm{~s}$ of the 30-min amplification time (Table 2) and some template-free controls. The alignment of the annealing curve for each sample to the positive control was used to visually assess true positive detection, with false positives denoted by no annealing curve or a short peak compared with the positive control and amplification of nontarget DNA often denoted by annealing curves not aligned to the positive control (with the curve positioned to the left or right of the positive control curve). However, considerable care was taken when using the curve alignment to decide false or true positives, because large differences in amplification time between Dactylonectria species also had an effect on the annealing curve alignment.

The assay at an isothermal amplification temperature of $69^{\circ} \mathrm{C}$ was demonstrated to have improved specificity, with no detection of isolates in the Calonectria, Cylindrocladiella, Gliocladiopsis, or Mariannaea genera or the template-free control (Table 2). Of the 16 representative isolates of Ilyonectria, which were selected from five different phylogenetic clades within this genus (Parkinson 2017), only 2 Ilyonectria sp. isolates, BRIP 61090 and BRIP 63711 (BRIP 63711f and BRIP 63711g are duplicate cultures of the same isolate), were detected in this assay (Table 2). These isolates are likely to represent two separate new species, and they were recorded only from one sample each in an Australia-wide fungal black root rot disease survey between 2013 and 2016 of healthy and symptomatic avocado trees and thus, are considered to have a very limited distribution (Parkinson 2017).

Experiment 4: LAMP diagnostic detection of target pathogens in fungal cultures. Experiment 4 tested the LAMP diagnostic design for detecting $C$. ilicicola, D. macrodidyma, and Dactylonectria spp. using aliquots of sd water containing fungal mycelia (Table 3 ).

In the $C$. ilicicola diagnostic (Table 3), all of the target species as pure cultures were detected between 15 and 29 min and $15 \mathrm{~s}$, averaging $\sim 16$ min for detection. None of the nontarget species as pure cultures were detected (Table 3). C. ilicicola was detected in two of three mixed cultures, with detection occurring between $17 \mathrm{~min}$ and $49 \mathrm{~s}$ and $24 \mathrm{~min}$ and $5 \mathrm{~s}$ (Table 3); the unknown Calonectria sp. was not detected.

In the D. macrodidyma diagnostic (Table 3), all of the target species as pure cultures were detected within $16 \mathrm{~min}$ and $30 \mathrm{~s}$ and $25 \mathrm{~min}$ and $15 \mathrm{~s}$. None of the nontarget species as pure cultures were detected (Table 3); $100 \%$ of mixed cultures containing the target species resulted in positive detection within $16 \mathrm{~min}$ and $15 \mathrm{~s}$ to $29 \mathrm{~min}$ and $20 \mathrm{~s}$ (Table 3 ). None of the mixed cultures containing only nontarget species showed detection (Table 3 ).

In the Dactylonectria genus-wide assay, $100 \%$ of Dactylonectria isolates had positive detection for both isothermal amplification temperatures (Table 3), with detection speeds ranging from 6 min and $30 \mathrm{~s}$ to $25 \mathrm{~min}$ and $15 \mathrm{~s}$. The detection time varied between the temperatures, suggesting that there was no link between detection speed and temperatures from 67 to $69^{\circ} \mathrm{C}$. Specificity was demonstrated at $69^{\circ} \mathrm{C}$, with no detection of $C$. ilicicola at this temperature compared with nonspecific detection at $25 \mathrm{~min}$ and $15 \mathrm{~s}$ at $67^{\circ} \mathrm{C}$ (Table 3).

Experiment 5: Validation of the LAMP diagnostic detection of target pathogens in inoculated avocado roots. This experiment tested the efficacy of the LAMP diagnostic on target species detection in symptomatic roots of inoculated avocado Reed seedlings. Each LAMP sample tested corresponded to a single plant inoculated with a pathogenic isolate or mixture of isolates (Table 4). Two diagnostic trials were conducted with freshly collected root tissue. Any detection after $30 \mathrm{~min}$ was considered to be nondetection, and this was confirmed by visual assessment of the annealing curve and temperature record. Any detection from $27 \mathrm{~min}$ and $30 \mathrm{~s}$ was subject to confirmation by visual assessment of annealing curves.

In the $C$. ilicicola assay, across two diagnostic trials, $C$. ilicicola was detected in $100 \%$ of plants inoculated with $C$. ilicicola alone, with detection time ranging from $12 \mathrm{~min}$ and $30 \mathrm{~s}$ to $24 \mathrm{~min}$ and 45 s (Table 4). However, C. ilicicola in one plant (plant \#23) was not detected in the first trial but was subsequently detected in the second trial. Across two diagnostic trials, eight of nine plants coinoculated with $C$. ilicicola had positive detection from $12 \mathrm{~min}$ and $45 \mathrm{~s}$ to $22 \mathrm{~min}$; C. ilicicola in plant \#11 was not detected in both trials, and two coinoculated plants of nine had positive detection in only one trial (Table 4). Nondetection occurred at $34 \mathrm{~min}$ and $15 \mathrm{~s}$ in one plant (plant \#5) of 24 and at $36 \mathrm{~min}$ and $45 \mathrm{~s}$ in the D. macrodidyma $50 \mathrm{ng} / \mu \mathrm{l}$ DNA sample (Table 4). There was no detection in healthy roots or template-free controls.

In the D. macrodidyma assay, across two diagnostic trials, $D$. macrodidyma was detected in $100 \%$ of plants inoculated with 
D. macrodidyma, with detection time ranging from 12 to $21 \mathrm{~min}$ (Table 4). However, one plant (plant\#14) was not detected in the first trial but was subsequently detected in the second trial. Across two diagnostic trials, $100 \%$ of plants coinoculated with $D$. macrodidyma were detected from $13 \mathrm{~min}$ and $30 \mathrm{~s}$ to $25 \mathrm{~min}$ and $30 \mathrm{~s}$. Nondetection of Dactylonectria spp. occurred at 39 min and $15 \mathrm{~s}$ in 3 of 24 plants (Table 4) across two diagnostic trials. There was no detection in healthy roots or template-free controls.

In the Dactylonectria genus-wide assay, across two diagnostic trials for each isothermal amplification temperature tested, the genus Dactylonectria was detected in $100 \%$ of plants inoculated or coinoculated with any species of the genus Dactylonectria, with detection time ranging $13 \mathrm{~min}$ and $45 \mathrm{~s}$ to $28 \mathrm{~min}$ and $45 \mathrm{~s}$ (Table 4) at $67^{\circ} \mathrm{C}$, and 17 of 19 plants $(\sim 89.5 \%)$ ranging from $9 \mathrm{~min}$ and $30 \mathrm{~s}$ to $29 \mathrm{~min}$ and $15 \mathrm{~s}$ at $69^{\circ} \mathrm{C}$. Within this group, 12 of 19 plants were detected in both of the diagnostic trials at $67^{\circ} \mathrm{C}$, and 10 of 19 plants were detected in both of the diagnostic trials at $69^{\circ} \mathrm{C}$. False negative detection occurred at $69^{\circ} \mathrm{C}$ in 3 of 19 plants in trial 1 and 4 of 19 plants in trial 2; at $67^{\circ} \mathrm{C}$, false negative detection occurred in 4 of 19 plants in trial 1 and 1 plant in trial 2. False positive detection of nontarget $C$. ilicicola occurred in trials of both isothermal temperatures tested, with detection times ranging from $17 \mathrm{~min}$ and $45 \mathrm{~s}$ to $28 \mathrm{~min}$ in $50 \mathrm{ng} / \mu \mathrm{l}$ DNA samples. In trial 1 at $67^{\circ} \mathrm{C}$, one of four plants inoculated with $C$. ilicicola alone resulted in false positive detection at $28 \mathrm{~min}$ and $45 \mathrm{~s}$; in trial 2 at $67^{\circ} \mathrm{C}, 50 \%$ of plants inoculated with C. ilicicola alone resulted in false positive detection from $27 \mathrm{~min}$ and $30 \mathrm{~s}$ to $27 \mathrm{~min}$ and $45 \mathrm{~s}$, whereas the other $50 \%$ resulted in nondetection after $30 \mathrm{~min}$. In trial 1 at $69^{\circ} \mathrm{C}$, only one plant inoculated with $C$. ilicicola alone resulted in false positive detection at $16 \mathrm{~min}$ and $45 \mathrm{~s}$. Template-free controls and healthy plants resulted in nondetection as indicated by detection after $30 \mathrm{~min}$ in all trials at both temperatures; however, false positive detection occurred at $27 \mathrm{~min}$ and $15 \mathrm{~s}$ in trial 1 at $67^{\circ} \mathrm{C}$.

\section{Discussion}

In this study, three LAMP diagnostic assays for detecting $C$. ilicicola, D. macrodidyma, and species in the Dactylonectria genus in avocado roots were developed from $\beta$-tubulin $(C$. ilicicola $)$ and histone H3 (D. macrodidyma and Dactylonectria spp.) fungal DNA sequence data. Five primers were designed for the species-specific assays, which included one loop primer to increase the specificity, sensitivity, and speed of the reaction, allowing reliable detection in avocado roots and fungal DNA of both target species within 30 min. Six primers, including two loop primers, were designed for the Dactylonectria genus-wide assay, with detection in avocado roots occurring within $30 \mathrm{~min}$. The speed of detection across all assays was fastest and most reliable for DNA extracts, with the detection speed decreasing as fungal cultures and plant tissue were introduced to the diagnostic.

The specificity of the diagnostic for detecting the target species or genus was found to be subject to time and isothermal amplification temperature, with specificity being most reliable in amplifications of $<30 \mathrm{~min}$ and temperatures of $67^{\circ} \mathrm{C}$ for detecting C. ilicicola and D. macrodidyma and $69^{\circ} \mathrm{C}$ for Dactylonectria spp. Nondetection was assumed at time points after $30 \mathrm{~min}$, and any detection after $27 \mathrm{~min}$ and $30 \mathrm{~s}$ was subject to the judgement of the user in checking for anneal curve consistency with the positive control to rule out false positive or nondetection. Nevertheless, nondetection after $30 \mathrm{~min}$ was less frequent in the species-specific assays compared with the genus-wide assay. False positives also did not occur at $<30 \mathrm{~min}$ for the species-specific assays compared with the genus-wide assay, which suggests that the species-specific assays are reliable for in planta detection of the target pathogens.

A limitation of the assay is the likelihood of false negatives, with some inoculated root samples in experiment 5 failing to amplify in one trial but amplifying in the second trial with a fresh batch of roots (Table 4). Although the majority of inoculated roots resulted in positive detection, the detection in avocado roots was found to be variable and possibly subject to the amount and quality of necrotic root tissue used in each sample. In preliminary work (data not shown) using too much necrotic root tissue (e.g., several necrotic roots $>1.5 \mathrm{~cm}$ ) often resulted in false negative detection; however, the detection rates improved when fewer roots (up to two necrotic roots $<1.5 \mathrm{~cm}$ ) were used, and these were also diluted by including a proportion of healthy roots (two to four healthy roots $<1.5 \mathrm{~cm}$ ) in the sample tube for extraction. Perhaps too much necrotic material may have an inhibitory effect on detection, and adjusting the concentration of fungal DNA using proportions helped to alleviate these effects. However, an accurate concentration of the target fungal DNA in the root tissue could not be determined, because the crude extracts contained target fungal DNA, avocado DNA, and DNA of soil microbial contaminants. Additional testing of the assays in field samples naturally infected with the pathogens should be done to fully validate the diagnostic, because artificial inoculation in the glasshouse may not represent varying pathogen titer in nursery or orchard environments. Nevertheless, the LAMP assays have been used for diagnostic testing of a symptomatic nursery tree submitted through the Australian nursery accreditation scheme, and C. ilicicola presence was confirmed and supported with identification by fungal isolation. LAMP detection speeds could provide an estimate of the fungal concentration, with faster speeds indicating higher target DNA; however, inhibitory compounds in the crude extract may also have an effect on the detection speed or success. Testing multiple samples of a single plant within the assay may also reduce the likelihood of false negative detection in a single diagnostic run.

The genus-wide Dactylonectria assay was demonstrated to have efficacy in detecting all Dactylonectria species available for testing, with no detection of representative isolates in the Cylindrocladiella, Gliocladiopsis, or Mariannaea genera; 2 of 16 representative isolates of the genus Ilyonectria selected were also detected in this assay (Table 2). The genus Ilyonectria is a close relative of the genus Dactylonectria, in which the latter genus was separated from the former in a multigene phylogeny study (Lombard et al. 2014). In the LAMP primer design phase, the genera Dactylonectria, Ilyonectria, and Calonectria shared multiple conserved regions within each gene examined, rendering it challenging to maintain $100 \%$ specificity for all species within the genus Dactylonectria while also excluding all species in the sister genera. A limitation found in primer design software for designing genus-wide LAMP primers was that the primer combinations produced did not satisfy full exclusion of species in closely related genera. Manual design of Dactylonectria genus-wide primers improved the specificity. However, the false positive detection of nontarget $C$. ilicicola in $<30 \mathrm{~min}$ in the Dactylonectria genus-wide assay demonstrated a shortfall in the primer design. For the purpose of the diagnostic assay in detecting multiple species in a known pathogenic genus, the LAMP primers could still be sufficient despite the chance of also detecting nontargets.

Some studies have demonstrated reliable detection without a DNA extraction step, with macerated plant tissue in water used directly as the DNA template (Fukuta et al. 2013). In LAMP studies by Fukuta et al. (2013), tomato roots were cut and placed into $1 \mathrm{ml}$ sd water. The solution was shaken for $1 \mathrm{~min}$. Then, $5 \mu \mathrm{l}$ solution was used as the LAMP DNA template for each reaction sample, and the LAMP assay was repeated three times (Fukuta et al. 2013). Other alternative extraction methods using $\mathrm{NaOH}$ and Tris- $\mathrm{HCl}$ buffers were outlined by Fukuta et al. (2003) for extraction of DNA from young tomato leaf tissue, which was then used as the DNA template in 25- $\mu$ l LAMP reactions. These methods were tested in preliminary avocado root tissue assays; however, there was inconsistent positive detection in inoculated avocado roots (data not shown), and DNA extraction with a commercial kit had improved the efficacy of the assays. DNA extraction from plant material using a lateral flow device (Tomlinson et al. 2010a, b) or with simple buffer solutions (Fukuta et al. 2003) could provide an alternative or potentially reduced cost DNA extraction before the LAMP reaction.

The findings of this study demonstrate the application and adoption of LAMP-based diagnostics in the Australian avocado industry. The simplicity of the testing method enables plant pathology service providers to use the tool as an initial test for confirming the presence of important pathogens in nurseries or orchards. Black root rot 
caused by nectriaceous pathogens poses a significant risk to new plantings in the first year after planting in the field, causing rapid decline and death (Parkinson et al. 2017). Although C. ilicicola is infrequently found in Australian avocado nurseries, Dactylonectria spp. have a higher prevalence (Parkinson 2017), and if either are present in the nursery, the potential loss in new orchard plantings could be devastating. Use of the LAMP assays for testing nursery trees routinely and before dispatching to orchards could potentially prevent industry-wide loss of new plantings in Australia. The LAMP primer sequences are available via publication, and the flexibility of the diagnostic procedure to be used with a range of reagents and equipment enables global accessibility. This diagnostic technology is not limited to testing in avocados, because the nectriaceous pathogens of interest are also important pathogens of various crops and ornamental plants, revealing an opportunity for use of this diagnostic tool across multiple agricultural industries around the world.

\section{Acknowledgments}

We thank the avocado nursery operators and growers who allowed us to collect samples to build our fungal isolate collection for this study. We also thank Dr. Yasushi Ishiguro from the River Basin Research Center, Gifu University for advice on the use of Primer Designer software. Hort Innovation is the grower-owned notfor-profit research and development corporation for Australian Horticulture.

\section{Literature Cited}

Adesemoye, A. O., Mayorquin, J. S., Peacock, B. B., Moreno, K., Hajeri, S., Yokomi, R., and Eskalen, A. 2016. Association of Neonectria macrodidyma with dry root rot of citrus in California. J. Plant Pathol. Microbiol. 8:391-394.

Auger, J., Pérez, I., and Esterio, M. 2015. Occurrence of root rot disease of cherimoya (Annona cherimola Mill.) caused by Dactylonectria macrodidyma in Chile. Plant Dis. 99:1282.

Dann, E. K., Cooke, A. W., Forsberg, L. I., Pegg, K. G., Tan, Y. P., and Shivas, R. G. 2012. Pathogenicity studies in avocado with three nectriaceous fungi, Calonectria ilicicola, Gliocladiopsis sp. and Ilyonectria liriodendri. Plant Pathol. 61:896-902.

Fang, Y., and Ramasamy, R. P. 2015. Current and prospective methods for plant disease detection. Biosensors (Basel) 5:537-561.

Fu, S., Qu, G., Guo, S., Ma, L., Zhang, N., Zhang, S., Gao, S., and Shen, Z. 2011. Applications of loop-mediated isothermal DNA amplification. Appl. Biochem. Biotechnol. 163:845-850.

Fukuta, S., Kato, S., Yoshida, K., Mizukami, Y., Ishida, A., Ueda, J., Kanbe, M., and Ishimoto, Y. 2003. Detection of tomato yellow leaf curl virus by loopmediated isothermal amplification reaction. J. Virol. Methods 112:35-40.

Fukuta, S., Takahashi, R., Kuroyanagi, S., Miyake, N., Nagai, H., Suzuki, H., Hashizume, F., Tsuji, T., Taguchi, H., Watanabe, H., and Kageyama, K. 2013. Detection of Pythium aphanidermatum in tomato using loop-mediated isothermal amplification (LAMP) with species-specific primers. Eur. J. Plant Pathol. 136:689-701.

Ghosh, R., Nagavardhini, A., Sengupta, A., and Sharma, M. 2015. Development of loop-mediated isothermal amplification (LAMP) assay for rapid detection of Fusarium oxysporum f. sp. ciceris - wilt pathogen of chickpea. BMC Res. Notes 8:40.

Halleen, F., Schroers, H.-J., Groenewald, J. Z., and Crous, P. W. 2004. Novel species of Cylindrocarpon (Neonectria) and Campylocarpon gen. nov. associated with black foot disease of grapevines (Vitis spp.). Stud. Mycol. 50:431-455.

Katoh, K., and Standley, D. M. 2013. MAFFT multiple sequence alignment software version 7: Improvements in performance and usability. Mol. Biol. Evol. 30:772-780

Kearse, M., Moir, R., Wilson, A., Stones-Havas, S., Cheung, M., Sturrock, S., Buxton, S., Cooper, A., Markowitz, S., and Duran, C. 2012. Geneious Basic: An integrated and extendable desktop software platform for the organization and analysis of sequence data. Bioinformatics 28:1647-1649.
Lechat, C., Groenewald, J. Z., and Crous, P. W. 2010. The enigma of Calonectria species occurring on leaves of Ilex aquifolium in Europe. IMA Fungus 1: 101-108.

Lombard, L., Van Der Merwe, N. A., Groenewald, J. Z., and Crous, P. W. 2014. Lineages in Nectriaceae: Re-evaluating the generic status of Ilyonectria and allied genera. Phytopathol. Mediterr. 53:515-532.

Malapi-Wight, M., Demers, J. E., Veltri, D., Marra, R. E., and Crouch, J. A. 2016. LAMP detection assays for boxwood blight pathogens: A comparative genomics approach. Sci. Rep. 6:26140.

Male, M. F., Tan, Y. P., Vawdrey, L. L., and Shivas, R. G. 2012. Recovery, pathogenicity and molecular sequencing of Calonectria ilicicola which causes collar rot on Carica papaya in Australia. Australas. Plant Dis. Notes 7:137-138.

Mori, Y., and Notomi, T. 2009. Loop-mediated isothermal amplification (LAMP) A rapid, accurate, and cost-effective diagnostic method for infectious diseases. J. Infect. Chemother. 15:62-69.

Nagamine, K., Hase, T., and Notomi, T. 2002. Accelerated reaction by loopmediated isothermal amplification using loop primers. Mol. Cell. Probes 16: 223-229.

Niessen, L. 2015. Current state and future perspectives of loop-mediated isothermal amplification (LAMP)-based diagnosis of filamentous fungi and yeasts. Appl. Microbiol. Biotechnol. 99:553-574.

Notomi, T., Mori, Y., Tomita, N., and Kanda, H. 2015. Loop-mediated isothermal amplification (LAMP): Principle, features, and future prospects. J. Microbiol. 53:1-5.

Notomi, T., Okayama, H., Masubuchi, H., Yonekawa, T., Watanabe, K., Amino, N., and Hase, T. 2000. Loop-mediated isothermal amplification of DNA. Nucleic Acids Res. 28:e63.

Ochi, S., Yoshida, M., Nakagawa, A., and Natsume, M. 2011. Identification and activity of a phytotoxin produced by Calonectria ilicicola, the causal agent of soybean red crown rot. Can. J. Plant Pathol. 33:347-354.

Parkinson, L. E. 2017. Investigating soilborne nectriaceous fungi impacting avocado tree establishment in Australia. PhD thesis. The University of Queensland, Brisbane, Australia.

Parkinson, L. E., Shivas, R. G., and Dann, E. K. 2017. Pathogenicity of nectriaceous fungi on avocado in Australia. Phytopathology 107:1479-1485.

Polizzi, G., Vitale, A., Aiello, D., Guarnaccia, V., Crous, P., and Lombard, L. 2012. First report of Calonectria ilicicola causing a new disease on Laurus (Laurus nobilis) in Europe. J. Phytopathol. 160:41-44.

Sankaran, S., Mishra, A., Ehsani, R., and Davis, C. 2010. A review of advanced techniques for detecting plant diseases. Comput. Electron. Agric. 72:1-13.

Tewoldemedhin, Y. T., Mazzola, M., Mostert, L., and Mcleod, A. 2011. Cylindrocarpon species associated with apple tree roots in South Africa and their quantification using real-time PCR. Eur. J. Plant Pathol. 129:637-651.

Tomita, N., Mori, Y., Kanda, H., and Notomi, T. 2008. Loop-mediated isothermal amplification (LAMP) of gene sequences and simple visual detection of products. Nat. Protoc. 3:877-882.

Tomlinson, J., Boonham, N., and Dickinson, M. 2010a. Development and evaluation of a one-hour DNA extraction and loop-mediated isothermal amplification assay for rapid detection of phytoplasmas. Plant Pathol. 59: 465-471.

Tomlinson, J., Dickinson, M., and Boonham, N. 2010b. Rapid detection of Phytophthora ramorum and $P$. kernoviae by two-minute DNA extraction followed by isothermal amplification and amplicon detection by generic lateral flow device. Phytopathology 100:143-149.

Úrbez-Torres, J. R., Peduto, F., and Gubler, W. D. 2012. First report of Ilyonectria macrodidyma causing root rot of olive trees (Olea europaea) in California. Plant Dis. 96:1378.

Vincelli, P., and Tisserat, N. 2008. Nucleic acid-based pathogen detection in applied plant pathology. Plant Dis. 92:660-669.

Vitale, A., Aiello, D., Guarnaccia, V., Perrone, G., Stea, G., and Polizzi, G. 2012. First report of root rot caused by Ilyonectria (=Neonectria) macrodidyma on avocado (Persea americana) in Italy. J. Phytopathol. 160: 156-159.

Wright, L., Davis, A., Wingfield, B., Crous, P., Brenneman, T., and Wingfield, M. 2010. Population structure of Cylindrocladium parasiticum infecting peanuts (Arachis hypogaea) in Georgia, USA. Eur. J. Plant Pathol. 127:199-206. 